\title{
Research on the influence of fuel gas on energy characteristics of a gas turbine
}

\author{
$G E$ Marin $^{1,2, *}, B M$ Osipov $^{1}$ and $D I$ Mendeleev $^{1,2}$ \\ ${ }^{1}$ Kazan State Power Engineering University, 420034, Krasnoselskaya Str., 51, Kazan, Russian Federation \\ ${ }^{2}$ JSC "Tatenergo" branch "Kazan CHP-2", 420036, Tatsevskaya St, 11, Kazan, Russian Federation
}

\begin{abstract}
The purpose of this paper is to study and analyze the gas turbine engine and the thermodynamic cycle of a gas turbine. The article describes the processes of influence of the working fluid composition on the parameters of the main energy gas turbines, depending on the composition of the fuel gas. The calculations of the thermal scheme of a gas turbine, which were made using mathematical modeling, are given. As a result of research on the operation of the GE PG1111 6FA gas turbine installation with various gas compositions, it was established that when the gas turbine is operating on different fuel gases, the engine efficiency changes. The gas turbine efficiency indicators were determined for various operating parameters and fuel composition. The impact of fuel components on the equipment operation is revealed.
\end{abstract}

\section{Introduction}

The problem of moral and physical aging of the power equipment park is very relevant now. Reconstruction and commissioning of new equipment of thermal power plants should be carried out using new technological solutions and new technologies. The energy strategy of the power engineering sector up to the year 2030 includes commissioning of new natural gas power units of combined-cycle gas turbine plants with capacities of 100, 200 and 450 MW. Gas turbine engines are currently widely distributed in combined-cycle power units when modernizing and replacing the equipment of power plants. [1-4]

Gas turbine engines use natural gas as a fuel gas, which is a mixture of hydrocarbons, the composition of which depends on the specific gas field. The gas composition determines the combustion process occurring in the combustion chamber, and the composition of the combustion products. When operating in the wholesale electricity market, a gas turbine unit (GTU) must produce the same power regardless of the gas composition [5-8].

\section{Purpose of the study}

This work aims to study the operating modes of a gas turbine installation, given the variability of the fuel gas properties depending on its field. [9]

The study of the gas turbine allows us to estimate changes in the basic energy and economic characteristics when the engine operation is converted to a specific composition of the fuel gas and to predict changes in these characteristics [10-11].
The PG1111 6FA gas turbine engine of General Electric was selected to assess the influence of fuel gas. The main characteristics of the gas turbine installation are presented in Table 1.

\section{Materials and methods}

During actual operation of combined-cycle gas turbines at combined heat and power (CHP) plants, gas turbine units operate in variable modes and the main indicators differ from that for the calculated modes. In this paper, the basic mode of operation of the equipment is considered.

For the study, a mathematical model of a gas turbine engine was created in the software package "Automated System of Gas-dynamic Research of Energy Turbomachines" (AS GRET). [12]

The functional diagram of the mathematical model is presented in figure 1; the selection window for elements for design scheme is presented in figure 2 .

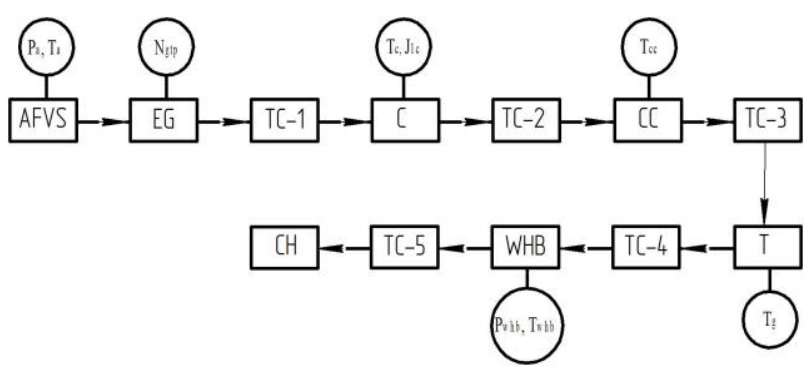

Fig. 1. The functional diagram of the mathematical model.

In Figure 1 the following designations are used: AFVS is Air Filtering and Conditioning System; EG is electric generator; TC-1 is transition channel between

* Corresponding author: george64199@mail.ru 
Table 1. The main characteristics of GTU (PG6111FA).

\begin{tabular}{|c|l|c|c|}
\hline No. & \multicolumn{1}{|c|}{ Characteristics } & Meas. unit & Value \\
\hline 1 & Power at the generator terminals & $\mathrm{kWh}$ & 77211 \\
\hline 2 & Atmosphere pressure & $\mathrm{kgf} / \mathrm{cm}^{2}$ & 1.013 \\
\hline 3 & Compressor inlet temperature & ${ }^{\circ} \mathrm{C}$ & 15 \\
\hline 4 & Relative humidity at the compressor inlet & $\%$ & 60 \\
\hline 5 & Pressure drop in the intake system & $\mathrm{mm} \mathrm{H}_{2} \mathrm{O}$ & 85 \\
\hline 6 & Static pressure at release under ISO conditions & $\mathrm{mm} \mathrm{H}_{2} \mathrm{O}$ & 350 \\
\hline 7 & Fuel temperature & ${ }^{\circ} \mathrm{C}$ & 30 \\
\hline 8 & Fuel pressure before the gas module & $\mathrm{kgf} / \mathrm{cm}^{2}$ & $25.9-30.8$ \\
\hline 9 & Power factor & & 0.85 \\
\hline 10 & The number of stages in the compressor & $\mathrm{pcs}$ & 18 \\
\hline 11 & The number of stages in the turbine & $\mathrm{pcs}$ & 3 \\
\hline 12 & Air flow & $\mathrm{m}^{3} / \mathrm{s}$ & 166 \\
\hline 13 & Compression ratio & & 15.8 \\
\hline 14 & Air temperature after the compressor & ${ }^{\circ} \mathrm{C}$ & 385 \\
\hline 15 & Flue gas temperature & ${ }^{\circ} \mathrm{C}$ & 603 \\
\hline 16 & Gas temperature after the combustion chamber & ${ }^{\circ} \mathrm{C}$ & 1325 \\
\hline
\end{tabular}

AFVS and compressor; $\mathrm{C}$ is compressor; TC-2 is the transition channel between the compressor and the combustion chamber; $\mathrm{CC}$ is combustion chamber; TC-3 is the transition channel between the combustion chamber and the turbine; $\mathrm{T}$ is turbine; $\mathrm{TC}-4$ is the transition channel between the turbine and the waste heat boiler; WHB is waste heat boiler; TC -5 is the transition channel between the waste-heat boiler and the chimney; $\mathrm{CH}$ is chimney.

The following assumptions are made in the calculations:

- Air flow rate $G=200 \mathrm{~kg} / \mathrm{s}$;

- Engine speed $n=5230 \mathrm{rpm}$;

- Compression ratio is 15.8 ;

- Inlet temperature $T=288.15 \mathrm{~K}$;

- Pressure at the compressor inlet $P=101.3 \mathrm{kPa}$;

- Gas turbine power $N=77 \mathrm{MW}$.

Tables 3 and 4 show the fuel composition of the North Stavropol gas field and the Kazan CHP-2.

Table 2. The fuel composition of the North Stavropol gas field.

\begin{tabular}{|c|c|c|c|c|c|}
\hline Component & Formula & $\begin{array}{c}\text { Molecular } \\
\text { weight }\end{array}$ & $\begin{array}{c}\text { Consistence } \\
\mathbf{k g} / \mathbf{m}^{\mathbf{3}}\end{array}$ & $\begin{array}{c}\text { Volumetric } \\
\text { composition \% }\end{array}$ & $\begin{array}{c}\text { Weight } \\
\text { composition, \% }\end{array}$ \\
\hline Methane & $\mathrm{CH}_{4}$ & 16.0426 & 0.668 & 98.68 & 97.355 \\
\hline Ethane & $\mathrm{C}_{2} \mathrm{H}_{6}$ & 30.06940 & 1.26 & 0.330 & 0.61 \\
\hline Propane & $\mathrm{C}_{3} \mathrm{H}_{8}$ & 44.10000 & 1.866 & 0.120 & 0.33 \\
\hline ISO-butane & $\mathrm{C}_{4} \mathrm{H}_{10}$ & 58.12400 & 2.491 & 0.050 & 0.179 \\
\hline Oxygen & $\mathrm{O}_{2}$ & 31.99880 & 1.331 & 0.020 & 0.049 \\
\hline Nitrogen & $\mathrm{N}_{2}$ & 28.01340 & 1.165 & 0.700 & 1.206 \\
\hline Carbon dioxide & $\mathrm{CO}_{2}$ & 44.01000 & 1.841 & 0.100 & 0.271 \\
\hline
\end{tabular}

Table 3. The composition of Kazan CHP-2 fuel gas.

\begin{tabular}{|c|c|c|c|c|c|}
\hline Component & Formula & $\begin{array}{c}\text { Molecular } \\
\text { weight }\end{array}$ & $\begin{array}{c}\text { Consistence } \\
\mathbf{k g} / \mathbf{m}^{\mathbf{3}}\end{array}$ & $\begin{array}{c}\text { Volumetric } \\
\text { composition \% }\end{array}$ & $\begin{array}{c}\text { Weight } \\
\text { composition, \%o }\end{array}$ \\
\hline Methane & $\mathrm{CH}_{4}$ & 16.0426 & 0.668 & 89.6 & 78.72 \\
\hline Ethane & $\mathrm{C}_{2} \mathrm{H}_{6}$ & 30.06940 & 1.26 & 5.920 & 9.747 \\
\hline Propane & $\mathrm{C}_{3} \mathrm{H}_{8}$ & 44.10000 & 1.866 & 2.360 & 5.699 \\
\hline ISO-butane & $\mathrm{C}_{4} \mathrm{H}_{10}$ & 58.12400 & 2.491 & 1.080 & 3.437 \\
\hline Oxygen & $\mathrm{O}_{2}$ & 31.99880 & 1.331 & 0.020 & 0.0439 \\
\hline Nitrogen & $\mathrm{N}_{2}$ & 28.01340 & 1.165 & 0.120 & 0.1841 \\
\hline Carbon dioxide & $\mathrm{CO}_{2}$ & 44.01000 & 1.841 & 0.900 & 2.169 \\
\hline
\end{tabular}




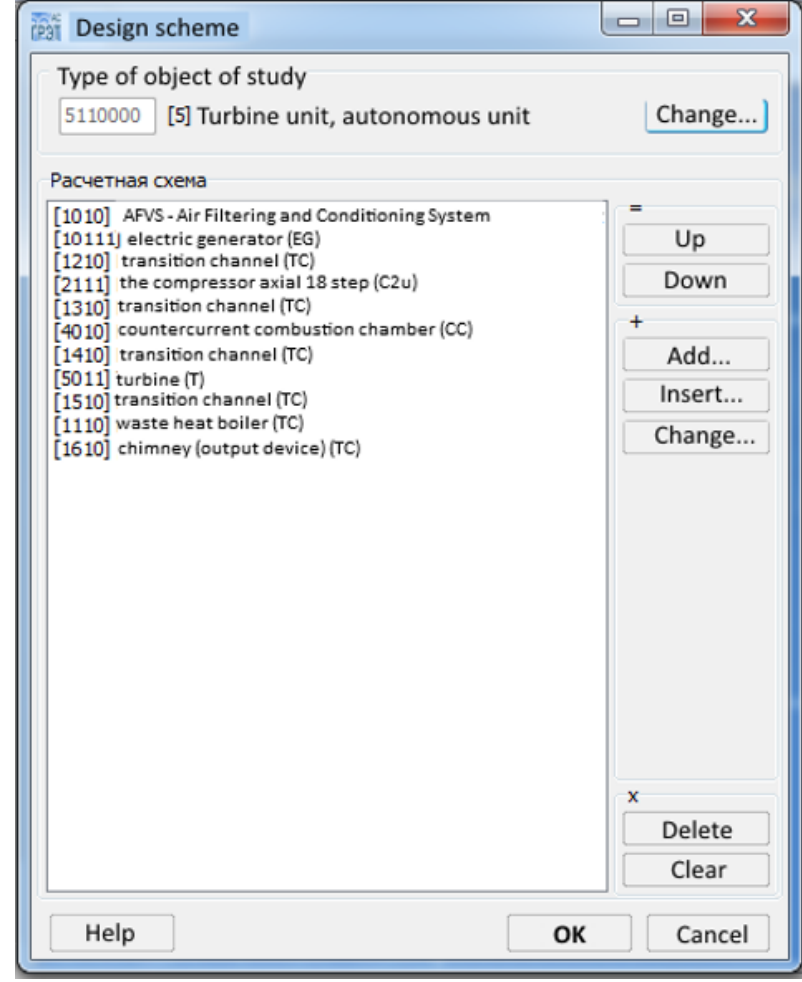

Fig. 2. Selection window for elements for design scheme.

\section{Results}

The performed research allowed us to obtain the following results:

1. The exhaust gas temperature after the gas turbine remained unchanged when working on both fuels, as the gas turbine operates as part of the combined cycle plant (CCP) power unit, and a steam turbine requires constant high and low pressure steam temperatures (Figure 3).

2. For different fuel gas compositions, the flow rate of gas entering the combustion chamber of the GTU will be different (Figure 4).

3. Various compositions of the fuel gas components also affect the gas turbine efficiency (Figure $5)$.

\section{Conclusions}

The fuel gas composition affects the characteristics and operation modes of gas turbine. In particular, the methane content in the fuel gas composition has a decisive influence on the energy characteristics of the gas turbine and on the performance of the installation as a whole. [13-15].

The fuel gas composition affects the energy characteristics of gas turbines, thus, when comparing

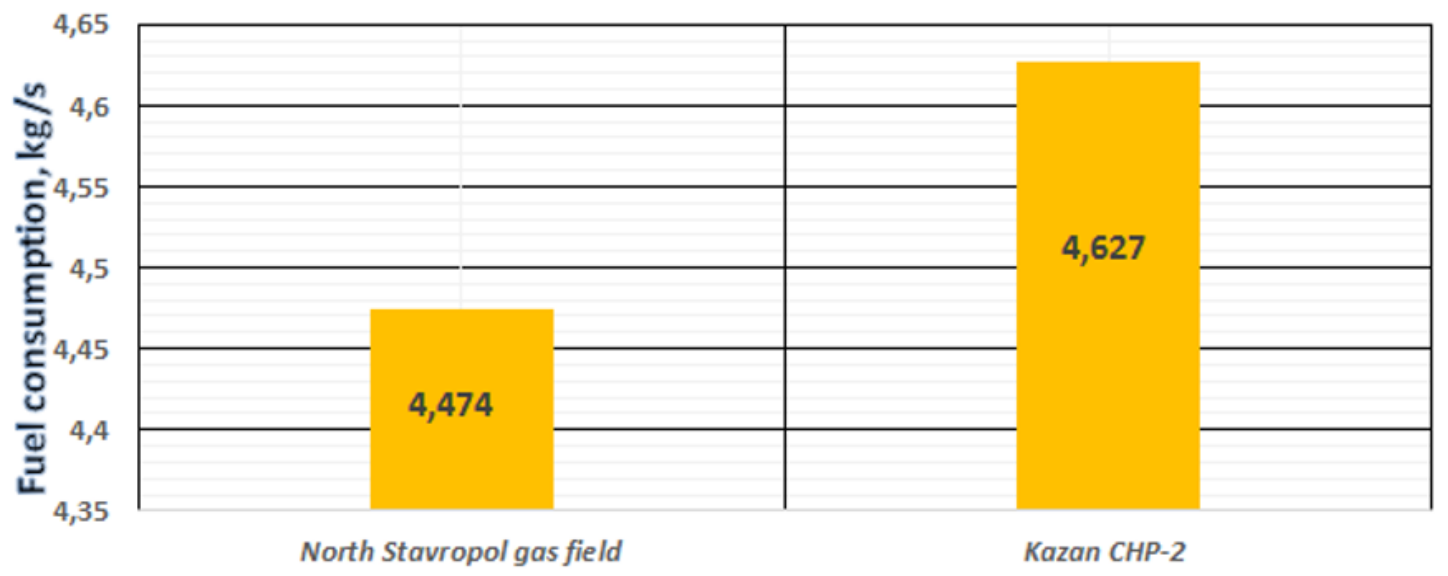

Fig. 4. Relationship between the gas flow entering the GTU combustion chamber and the fuel type.

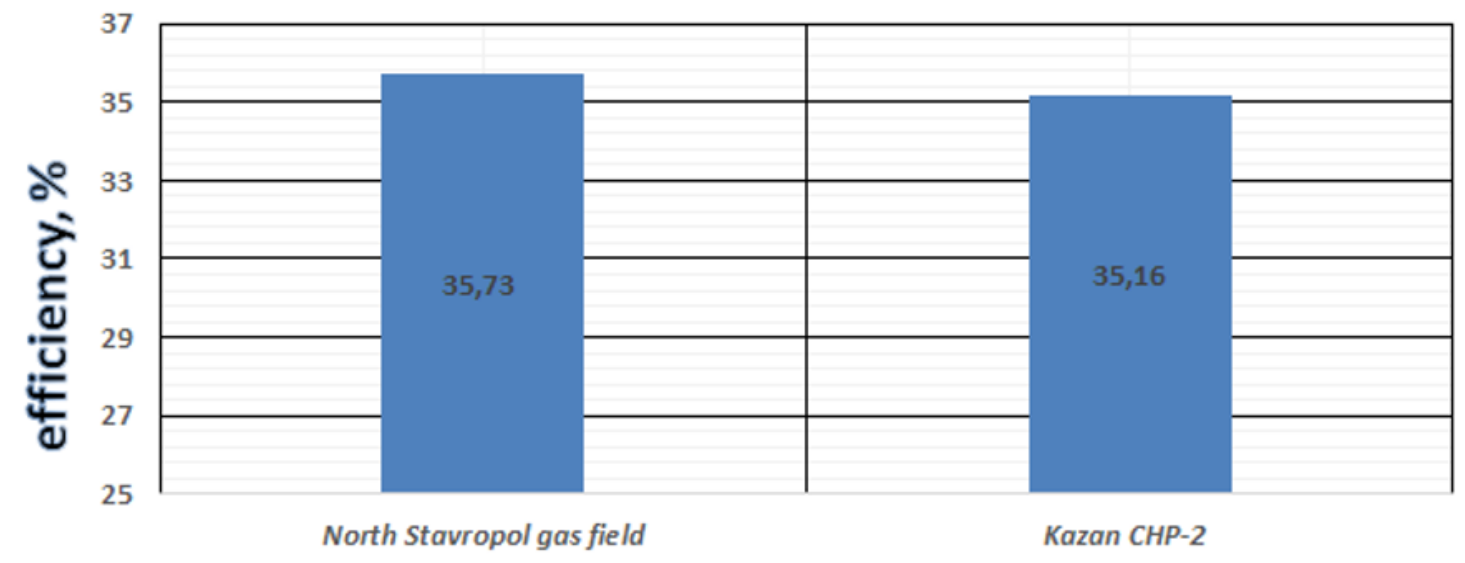

Fig. 5. Dependence of gas turbine efficiency on fuel type. 
two fuels the fuel gas consumption changes by $1.03 \%$, while the increase in efficiency will be $1.01 \%$.

Therefore it is important to pay attention on the choice of fuel (its gas field) and its characteristics that may also change over time, and therefore affect various indicators of a particular installation or the entire equipment in the complex (for example, in case when GTU is an integral part of a combined cycle plant).

\section{References}

1. J. Kotowicz, M. Job, M. Brzeczek, The characteristics of ultramodern combined cycle power plants, Energy, 92(12), 197-211 (2015) doi: 10.1016/j.energy.2015.04.006.

2. A.M.Y. Razak, Industrial Gas Turbines: Performance and Operability, Industrial Gas Turbines: Performance and Operability, 1-602, (2007) doi: 10.1533/9781845693404.

3. T.A. Clifford, S. Cruz-Manzo, Y. Zhang, V. Panov, A. Latimer, Development of a Steady-State Thermodynamic Model in Microsoft Excel for Performance Analysis of Industrial Gas Turbines, Annual Conference of the Ieee Industrial Electronics Society, Proceedings Paper, 43, 4717 4723 (2017)

4. D.I. Mendeleev, G.E. Marin, Factors affecting the ability of the CCGT unit to generate a given power and the fulfillment of a given electrical load curve, Modern technology in the energy sector. AllRussian Specialized Scientific and Practical Conference of Young Specialists, 36-40 (2018)

5. A. Madhlopa, Gas Turbine Fuels and Fuel Systems in Principles of Solar Gas Turbines for Electricity Generation, Green Energy and Technology, 27-49 (2018)

6. A. Alajmi, N.M. Adam, A.A. Hairuddin, L.C. Abdullah, Fuel atomization in gas turbines: A review of novel technology, International Journal of Energy Research, Review, 43(8), 3166-3181 (2019) doi: $10.1002 / \mathrm{er} .4415$.

7. O.A. Khudair, K.A. Abass, N.S. Abed, K.H. Ali, S. AbdulAziz, A.C. Shaboot, Theoretical Investigation For The Effect of Fuel Quality on Gas Turbine Power Plants in Ibn Al-Haitham, 1st International Scientific Conference on Biology, Chemistry, Computer Science, Mathematics, and Physics (IHSCICONF), 1003 (2018) doi: 10.1088/17426596/1003/1/012022.

8. K.X. Liu, S. Sadasivuni, N. Parsania, Industrial gas turbine engine response and combustion performance to fuel changeovers in compositions and heating values, Fuel, Article, 242(4), 507-519 (2019) doi: 10.1016/j.fuel.2019.01.030.

9. A. Tsai, P. Pezzini, D. Tucker, K.M. Bryden, Multiple-Model Adaptive Control of a Hybrid Solid Oxide Fuel Cell Gas Turbine Power Plant Simulator, Journal of Electrochemical Energy Conversion and Storage, 3(16), 11 (2019) doi: $10.1115 / 1.4042381$.
10. L.K. Zheng, J. Cronly, E. Ubogu, I. Ahmed, Y. Zhang, B. Khandelwal, Experimental investigation on alternative fuel combustion performance using a gas turbine combustor, Applied Energy, 238, 15301542 (2019) doi: 10.1016/j.apenergy.2019.01.175.

11. L.K. Zheng, Effects of Alternative Fuel Properties on Particulate Produced in a Gas Turbine Combustor, Energy \& Fuels, 32, 9883-9897 (2018) doi: 10.1021/acs.energyfuels.8b01442.

12. B.M. Osipov, A.V. Titov, Automated system of gasdynamic calculations of energy turbomachines. Proc. manual, 277 (2012)

13. L. Esclapez, Fuel effects on lean blow-out in a realistic gas turbine combustor, Combustion and Flame, 181, 82-99 (2017) doi: 10.1016/j.combustflame.2017.02.035.

14. P. Lokini, D.K. Roshan, A. Kushari, Influence of Swirl and Primary Zone Airflow Rate on the Emissions and Performance of a Liquid-Fueled Gas Turbine Combustor, Journal of Energy Resources Technology-Transactions of the Asme, 141(6), 9 (2019) doi: 10.1115/1.4042410.

15. T. Zornek, T. Mosbach, M. Aigner, Optical Measurements of a Lower Calorific ValuesCombustor Operated in a Micro Gas Turbine With Various Fuel Compositions, Journal of Engineering for Gas Turbines and Power-Transactions of the Asme, 141(4), 4 (2019) doi: 10.1115/1.4040908. 